* Graduado em Direito pela Faculdade de Ciências Aplicadas e Sociais de Petrolina. E-mail: erick-almeida@live. com

** Doutora em Programa de Doutoramento de Filosofia pela Universidade de Évora. Mestre em Educação pelo Instituto Internacional Universitário do Brasil. Especialista em contabilidade e controladoria pela Universidade Federal de Pernambuco. Especialista em Metodologia da Pesquisa na Educação Fundamental pela Universidade de Pernambuco. Graduada em Administração pela Faculdade de Ciências Aplicadas e Sociais de Petrolina. Docente da Faculdade de Ciências Aplicadas e Sociais de Petrolina.

E-mail:zelia.ramos@hotmail.

com

*** Pós-graduada em Direito Público pela Universidade do Estado da Bahia. Graduada em Engenharia Agronômica e Direito pela Universidade do Estado da Bahia. Docente da Faculdade de Ciências Aplicadas e Sociais de Petrolina.

E-mail:chirley.cordeiro@ facape.br

\section{Direito À Felicidade: ANÁlise Principiológica e Desdobramentos no OrdenAMENTo JuRídico Brasileiro}

The Right to Happiness: PrinCIPIOLOGICAL ANALYSIS AND ITS UNFOLDING IN THE BRAZILIAN LEGAL ORDER

\section{Erik Almeida Rodrigues de Souza* Zélia Maria Xavier Ramos** Chirley Vanuyre Vianna Cordeiro***}

Como citar: SOUZA, Erik Almeida Rodrigues de; RAMOS, Zélia Maria Xavier; CORDEIRO, Chirley Vanuyre Vianna. Direito à felicidade: análise principiológica e desdobramentos no ordenamento jurídico brasileiro. Revista do Direito Público, Londrina, v. 13, n. 2, p.100-137, ago. 2018. DOI: $10.5433 / 24157-108104-1.2018 v 13 n$ 2p100. ISSN: 1980-511X.

Resumo: $O$ presente artigo visa analisar a existência do direito à felicidade como um princípio constitucional implícito no ordenamento jurídico brasileiro e seus desdobramentos a partir de sua aplicação. Para chegar nesse objetivo, calcado em coleta de dados bibliográfica, este trabalho começa trazendo apontamentos de diversos pensadores sobre a definição de felicidade e o seu encaixe como conceito jurídico indeterminado. Perpassada estas questões, há a demonstração do revestimento principiológico do direito à 
felicidade, assim como a apresentação da evolução da normatividade dos princípios, obtida com o pós-positivismo. Prosseguindo, segue-se indicando os desdobramentos do direito à felicidade, consistentes em direito à busca da felicidade, direito prestacional à felicidade e como telos das decisões judiciais. Após, há a exposição do direito ora em estudo positivado em constituições mundiais, quais sejam em Butão, Coréia do Sul, Estados Unidos, França e Japão, e, por fim, parte da experiência jurisprudencial brasileira, que traz a felicidade em decisões diversas.

Palavras-chave: Direito à felicidade. Direito constitucional. Hermenêutica. Princípio constitucional implícito.

Abstract: This paper analyzes the right to happiness as a constitutional principle implicit in the Brazilian legal order. Furthermore, this study explores its unfolding and application from a judicial perspective; in order to reach this objective, this research collected data, notes and answers from various legal scholars regarding the following question: what is the definition of happiness, as it is, today, an ambiguous legal concept. Within this context, this research presents the right to happiness' principiological undertakings, and studies the evolution of its normative principles - steadily obtained with the postpositivism movement. Furthermore, this paper concludes that the right to happiness, encompassing the right 
to pursuit happiness, needs be guaranteed as a teleological motive in judicial decisions, only then can it be exercised freely. In conclusion, the right to happiness is guaranteed in innumerous constitutions-e.g. Bhutan, South Korea, United States of America, France and Japan; yet, in Brazil it is frequently present as a rationale in judicial decisions.

Keywords: Right to happiness. Constitutional law. Hermeneutics. Implicit constitutional principle. 


\section{INTRODUÇÃO}

Quem protege a felicidade humana? São vastas as áreas do conhecimento e expressão humana que indagam e abordam a felicidade que está contida nas ciências, nas artes e até mesmo nas metas de projetos pessoais. Esse assunto tão presente no cotidiano humano, individual e coletivo, não poderia ser afastado das discussões jurídicas, afinal, o Direito está intrinsecamente ligado às condutas sociais.

Tratando-se dessa temática no âmbito jurídico, é natural questionar inicialmente o significado de felicidade. Não se sabe, com precisão, o que ela é ou como ela se dá. Séculos de estudos, observações e indagações científicas não conseguiram, ainda, responder exaustivamente a essa celeuma. O fato é que o desejo de ser feliz compõe os anseios existentes dentro de cada pessoa humana e, embora haja uma gama de motivos legítimos que fazem as pessoas felizes, não se deve repulsar a proteção jurídica da felicidade.

Apesar de não expressamente positivado o direito à felicidade, $\mathrm{o}$ ordenamento jurídico brasileiro engatinha no sentido do seu resguardo, pois esse direito compõe, ainda que indiretamente, pretensões jurídicas e decisões judiciais.

É nesse ponto que reside o interesse deste trabalho, apontando os desdobramentos do direito amplo à felicidade como um princípio constitucional implícito, de acordo com sua aplicação jurídica.

Alicerçado em coleta de dados bibliográfica, este artigo busca a compreensão da felicidade como um conceito jurídico indeterminado, a sua configuração principiológica, bem como as suas diferentes facetas conforme a perspectiva de sua execução. Como procedimento metodológico, optou-se por investigar os aportes teóricos jurídicos 
das leis e, como reforço à fundamentação do estudo, foi importante a utilização da pesquisa documental.

Para alcançar a finalidade proposta, numa tentativa de análise no formato explicativo e compreensivo das dimensões que envolvem a busca da felicidade, em que o conhecimento e realidade se dão numa relação dialética e histórica, primeiramente precisa-se ter uma noção da diversidade conceitual que engloba a felicidade. Isso é feito na seção dois, quando se trazem lições de diversos pensadores e teóricos sobre o assunto, assim como apontamentos sobre a felicidade coletiva, considerada também de salutar importância. Por fim, há a inserção do entendimento de felicidade dentro dos conceitos jurídicos indeterminados, ante a turbidez do seu significado.

Seguidamente, na seção três, é feito o encaixe do direito à felicidade no manto dos princípios jurídicos constitucionais implícitos, em face do seu revestimento axiológico. Obtida essa abordagem, prossegue-se explanando a evolução da normatividade dos princípios nas correntes do Direito positivista e pós-positivista, bem como o impacto desse progresso no ordenamento jurídico.

Na seção quatro discorre-se sobre as facetas do direito amplo à felicidade, tratado como princípio, desdobrando-se em direito à busca da felicidade, direito prestacional à felicidade e sua aplicação como telos das decisões judiciais.

A menção ao direito à felicidade em algumas das constituições internacionais é feita na seção cinco. A tratativa desse tema é importante para demonstrar como alguns outros países protegem o direito à felicidade e que, aos poucos, ele vem penetrando o ordenamento jurídico brasileiro, conforme se expõe na seção seis. Nesta seção final é trazida, depois de discorridas as questões nucleares do trabalho, parte da experiência 
jurisprudencial brasileira que, em suas decisões, abarcam a felicidade.

\section{CONSIDERAÇÕES SOBRE A FELICIDADE}

\subsection{Da felicidade e sua diversidade conceitual}

O imbróglio entre os juristas é saber conceituar a felicidade. Inexiste entendimento absoluto sobre a temática, todavia há esforços de teóricos para chegar a uma significação apropriada.

Para ilustrar a afirmativa, pode-se recorrer a Sócrates. Ao conceituar a felicidade, ele fez uma diferenciação entre o prazer virtuoso e o prazer vulgar. O primeiro seria resultante da prática de filosofar, sendo superior ao segundo, que decorreria da alimentação e do coito. Assim, para o pensador, a reflexão seria elemento integrador da felicidade. Com essa ideia, é possível a descaracterização de determinados prazeres como integrantes da felicidade - a exemplo do prazer perverso - por serem emanantes de condutas sádicas (LEAL, 2013, p. 15).

Assemelhando-se à filosofia socrática, Leal (2013) qualifica Platão como idealizador da felicidade consistente em uma harmonia de objetivos que o indivíduo, ao descobrir o que é a verdadeira virtude, praticaria. Ainda nessa teoria, Platão acreditava ser a felicidade a ausência dos excessos, mesmo que prazerosos, priorizando o pensamento, a disciplina e o autocontrole. Para ele, ser feliz era "fugir do que supunha levar à felicidade".

De acordo com as perspectivas de Sócrates e Platão, afasta-se o senso comum de que a felicidade seria a mera satisfação dos desejos. O ser humano, como ser reflexivo, tornar-se-ia feliz quando distante da perversão e das condutas excessivas. 
Aristóteles (2003), em sua obra Ética a Nicômaco, indica que a felicidade seria o maior bem do homem, "uma atividade virtuosa da alma, de certa espécie". Para ele, a felicidade consistiria na prática das virtudes e valores eleitos desde as antigas sociedades, estaria associada à atividade baseada no "bem sumo" e nas virtudes. Seria ainda, segundo o autor, uma "atividade conforme à virtude" (ARISTÓTELES, 2003, p. 29).

Conforme o filósofo grego, a virtude humana não seria a do corpo, mas a da alma. Para que essa virtude fosse alcançada, Aristóteles revelou a importância dos bens exteriores na construção da felicidade, pois “[...] é impossível, ou pelo menos não é fácil, praticar ações nobres sem os devidos meios. Em muitas ações usamos como instrumentos os amigos, a riqueza e o poder político; [...]" (ARISTÓTELES, 2003, p. 30). Conforme Bittar (2011, p. 230-231):

A felicidade é o bem supremo (aristón), o mais belo (kallistón) e o mais prazeroso (édiston); o prazer é conceitualmente parte da felicidade, porém não toda ela, nem qualquer prazer, mas o maior dos prazeres. Nessa perspectiva, a felicidade reside numa disposição efetiva da alma, de acordo com a virtude; acentua-se que se trata de uma disposição anímica efetiva, pois a possessão da virtude não pode ser separada de sua prática (práxis). A posse da virtude em sua integralidade, aliada à sua prática (práxis), confere ao sujeito que o possui um gozo que, além de não efêmero, é usufruído independentemente de qualquer outra coisa. Mesmo assim, esse gozo não deixa de depender da concorrência de uma série de outros bens, que não aqueles da alma, quais sejam, os corporais ou físicos (saúde, rigidez das carnes, perfeição dos órgãos, beleza, proporção das partes do corpo...) e os exteriores (amizade, honra, poder, riqueza...).

Ao explanar o conceito aristotélico de felicidade, Bittar (2011) 
engloba-o como um conceito puramente humano, por ser visto como uma "atividade de acordo com a virtude". Como atividade pressupõe ação humana, descarta-se de logo a possibilidade de ser dada ao homem inerte, bem como de ser saboreada na fase pós-morte.

Em uma concepção mais atual, Márcia Tiburi (2007) considera que a concepção virtuosa da felicidade não é perfeitamente encaixada hodiernamente na sociedade, mas que seu cerne virtuoso necessita ser resgatado:

Não podemos, é óbvio, pensar que a felicidade tal como concebia Aristóteles nos serve hoje. A felicidade só pode ser pensada com base na sua evolução histórica. Havia, porém, aquele aspecto da felicidade que não levamos em conta em nossos dias e que precisa ser recuperado. É preciso lembrar que a felicidade era, em Aristóteles, um ideal ético da vida. A vida ética era a vida justa, boa, corretamente vivida por um cidadão, alguém que sabia de seu papel na sociedade, que ao pensar em si levava em conta o todo: família, amigos, sociedade, natureza (TIBURI, 2007, p. 50).

Distanciando-se um pouco de Aristóteles, Epicuro (2002), na obra Carta Sobre a Felicidade, baseou seu ideal de felicidade em uma visão sensualista - dos sentidos. Para ele, a vida feliz do ser humano seria composta de ausência de dor, existência de desejos moderados e eliminação de certas crenças. Isso faria com que o indivíduo não sofresse com a criação de expectativas sobre a vida.

A visão de Epicuro se assemelha à de Kant apud Tiburi (2007), cuja ideia de felicidade valorizava a liberdade e a dignidade humana, bem como a emersão da sociedade, antes mergulhada na ignorância e na superstição. Para Kant, o máximo que o homem conseguiria era a dignidade de ser feliz, e não se tornar realmente feliz, nestes termos: 
Hoje, uns acham, como Kant, a felicidade impossível, outros tratam-na como algo banal, mera realização de prazeres pessoais. O desentendimento quanto à felicidade apenas mostra que ela não está bem situada como conceito dentro de nossas vidas. Apenas aqueles que puderem pensá-la como potência ética, como algo que se constrói na fusão da vida pessoal com a vida pública é que podem continuar falando de felicidade. Antes de ser feliz devo perguntar se posso ser ético. Será mais fácil ser feliz (TIBURI, 2007, p. 51).

À vista do conceito de felicidade como satisfação dos prazeres pessoais, mais a ausência de dor, John Stuart Mill (2005) levanta pesadas críticas. O autor considera tal ideia desprezível, tendo em vista que equipararia a vida humana à mera existência vegetativa, assemelhando homens a porcos - seres meramente animalescos. Afinal, o propósito de prazer dos bichos seria diferente dos que concerne aos humanos, que precisam de muito mais que a satisfação dos desejos para ser feliz.

Por seu turno, Daniel Gilbert (2006), professor de Psicologia na Universidade de Harvard, descreve a felicidade como uma emoção que os indivíduos não sabem conceituar, contudo, sabem apontar sua causa. O profissional indica que a felicidade emocional estaria ligada às experiências:

Happiness, then, is the you-know-what-I-mean feeling. If you are a human being who lives in this century and shares some of my cultural conditioning, then my pointing and comparing will have been effective and you will know exactly which feeling I mean. [...] Because emotional happiness is an experience, it can only be approximately defined by its antecedents and by its relation to other experiences (GILBERT, 2006, p. 33). ${ }^{1}$

1 Felicidade é, então, o sentimento "você-sabe-qual". Se você é um humano que vive neste século e 
A pesquisa realizada por Leaf Van Boven (2005), na Universidade do Colorado, exemplifica o que é trazido por Daniel Gilbert, quando conclui que as pessoas que possuem metas materialistas seriam mais infelizes e suscetíveis a desordens psicológicas. Em contrapartida, os indivíduos que se utilizam de recursos materiais na busca de experiências na vida seriam mais felizes.

O pensamento de Gilbert (2006) está em consonância também com o entendimento de felicidade do filósofo brasileiro Mário Sérgio Cortella, que descreve a felicidade como uma "vibração intensa", de alto nível, sendo uma sensação de vitalidade, plenitude, que atinge o ser humano e o deixa com imenso gosto por estar vivo. Acrescenta o filósofo que "a felicidade é episódica, uma ocorrência eventual" (SOSNOWSKI, 2013).

Malgrado haja discrepâncias acerca do entendimento sobre a felicidade, a visão aristotélica é a mais acatada nos trabalhos dos estudiosos. É embasando-se nela que John Rawls apud Leal (2013) indica que a pessoa é feliz quando seus planos racionais ganham execução: seus objetivos mais importantes tendem a se concretizar e esse cenário de realização persiste durante a vida. Além disso, para Rawls apud Leal (2013), a felicidade seria escolhida como um valor em si mesmo, ou seja, ela é autossuficiente. Não é um objetivo dentre outros aos quais se aspira, mas é a plena concretização do desígnio.

\subsection{Da felicidade coletiva}

compartilha de minha condição cultural, então meu ponto e comparação terão sido efetivos e você irá saber exatamente sobre qual sentimento estou tratando. [...] Porque felicidade emocional é uma experiência, isso só pode ser aproximada definida por seus antecedentes e por sua relação a outras experiências. Tradução de responsabilidade deste autor. 
Trazendo apontamentos de Albornoz, Beatriz Rubin (2010), inicialmente, argumenta ser a busca da felicidade coletiva algo utópico, porém verdadeiro, real e digno, tanto por ser altruísta quanto porque, tratando-se de expressão coletiva, resta traduzida a sua possibilidade real, in verbis:

A felicidade da superação das fomes humanas, inclusive do respeito aos direitos humanos, que correspondem à ideia da dignidade humana, atualmente é esperança. Mas não é "mera esperança", como algo que se posterga indefinidamente e deva ser classificado entre as ilusões ou, quem sabe, entre as superstições da humanidade. É esperança fundada na realidade, porque o desenvolvimento científico e técnico e a capacidade de produção dos homens já tornou este sonho apto a tornar-se realidade, só sendo necessária a conjunção das condições objetivas com as subjetivas, ou seja, a superação da "estultice culpada", dos enganos e desvios políticos e morais, da decisão humana e da liberdade. Em outros termos, para que a felicidade coletiva possa começar a tornar-se realidade, $o$ desenvolvimento necessário é mais do plano da "vontade política", do aperfeiçoamento cultural e psicológico, do que antes se diria como "espírito", pois as condições materiais estão dadas (ALBORNOZ apud RUBIN, 2010, p. 44).

\subsection{Do utilitarismo}

De outra banda, não há como tratar de felicidade coletiva sem mencionar a teoria utilitarista. De acordo com Leal (2013), Jeremy Bentham foi o mais notável dos precursores da teoria do utilitarismo. Sua teoria da "felicidade maior" assevera que qualquer decisão, pública ou privada, deveria ser ponderada de acordo com o nível de felicidade que cada uma proporcionaria a cada grupo de pessoas que lhe diz respeito, 
cada indivíduo contando igualmente. Consoante explanado por Leal (2013, p. 55):

Pelo princípio da utilidade poderíamos nos valer de um mal, desde que o fosse para impedir um mal ainda maior. Bentham chega a dizer que "não é necessário consultar Platão ou Aristóteles. Dor e prazer são o que todos sentem como tais - o mendigo e o príncipe, o iletrado e o filósofo" - afirmou.

Aperfeiçoando a ideia de Bentham, Mill (2005) considera que o princípio da felicidade maior abarca a ideia de que ser feliz seria o objetivo superior do indivíduo. Ele pode ter vários anseios, todavia, todos esses irão compor um desejo maior, que é a felicidade. Acrescenta-se a isso a diminuição da dor, a riqueza de deleites - na medida do possível - respeitados os parâmetros de qualidade e quantidade.

Feita a comparação entre a evolução do estudo de Bentham por Mill, é notável um refinamento. O primeiro não levou em conta, ao tratar de felicidade coletiva, a quantidade e a qualidade da dor e do prazer, o que fora posto em consideração pelo segundo, trazendo assim maior consistência à teoria.

Mill (2005) acrescenta, ainda, que a felicidade que "constitui o padrão utilitarista daquilo que está certo na conduta não é a felicidade do próprio agente, mas a de todos os envolvidos". Diante da escolha da felicidade própria ou da felicidade dos outros, deve o indivíduo decidir de forma imparcial, agindo como um espectador benevolente e desinteressado. $\mathrm{O}$ autor, então, retrata:

Na regra de ouro de Jesus de Nazaré, lemos todo o espírito da ética da utilidade. Tratar os outros como queremos que nos tratem e amar o nosso próximo como a nós mesmos 
constituem a perfeição ideal da moralidade utilitarista. Quanto aos meios para a máxima aproximação a este ideal, a utilidade prescreve, em primeiro lugar, que as leis e estruturas sociais coloquem tanto quanto possível a felicidade ou (como se lhe pode chamar para falar em termos práticos) o interesse de qualquer indivíduo em harmonia com o todo, e, em segundo lugar, que a educação e a opinião, que têm um poder tão grande sobre o carácter humano, usem esse poder para estabelecer na mente do indivíduo uma associação indissolúvel entre a sua própria felicidade e o bem comum, especialmente entre a sua própria felicidade e a prática daqueles modos de conduta, negativos e positivos, que a consideração pela felicidade universal prescreve, não só de maneira a que o indivíduo seja incapaz de conceber consistentemente a possibilidade de ser feliz agindo contra o bem geral, mas também de maneira a que um impulso directo para promover o bem geral possa ser um dos habituais motivos para agir em todos os indivíduos, e que os sentimentos ligados a esse impulso possam ocupar um lugar amplo e proeminente na existência senciente de todos os seres humanos (MILL, 2005, p. 58).

\subsection{Direito à felicidade - conceito jurídico indeterminado?}

Quando se analisa um conceito, deve-se ter em mente uma zona nuclear (fixa) - em que são estabelecidas as certezas - e outra periférica - parte em que se iniciam as dúvidas.

Tratando-se de conceito indeterminado, existe uma zona nuclear que se apresenta de forma reduzida, assim como uma área periférica que se apresenta de forma extensa e difusa.

Já diante de um conceito jurídico indeterminado, tem-se a possibilidade de controle jurídico, ao manusear sua zona nuclear. Embora haja indeterminação, existe no conceito uma área de certeza negativa - o que certamente não é - e outra área de certeza positiva - o que certamente 
é. Isso é imprescindível para afastar interpretações e aplicações incorretas, embora persista a zona de incerteza e penumbra. (LAMY, 2007, p. 53-54).

E por conta disso, em face da polpa conceitual diversificada que ora se apresentou, é pertinente encaixar a ideia de felicidade, ao manuseála dentro do Direito, no rol dos conceitos jurídicos indeterminados.

\subsection{A felicidade nas Constituições}

O direito à felicidade não é expressamente tratado na Constituição Federal da República Federativa do Brasil de 1988. Em 2010, a Proposta de Emenda à Constituição - $\mathrm{PEC} \mathrm{n}^{\circ} 19$, de 2010, apresentada pelo senador Cristovam Buarque (BRASIL, 2010a), tentou incluir, sem sucesso, o direito à busca da felicidade no caput do artigo $6^{\circ}$. Em seu embasamento, a referida PEC mencionava a adoção expressa do direito à felicidade no texto constitucional de diversos países.

Para ilustrar, menciona-se que nos Estados Unidos, de acordo com Conklin (2015), a Declaração de Independência de 1776 abarcou a busca da felicidade no rol de direitos inalienáveis, junto à vida e à liberdade, em inclusão feita por Thomas Jefferson, baseando-se no trabalho de John Locke. O autor do artigo The Origins Of The Pursuit

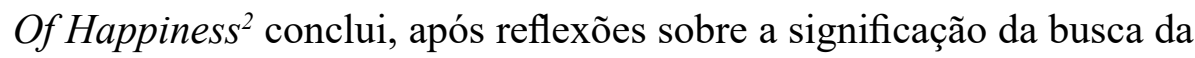
felicidade na história e jurisprudência norteamericana, que esse direito não é uma garantia estatal de que todos serão felizes, mas de que os indivíduos livres podem se engajar na busca da felicidade:

As contained in Blackstone's Commentaries and the Declaration of Independence, the pursuit of happiness

2 As Origens do Direito à Busca da Felicidade. Tradução de responsabilidade destes autores. 
is not a legal guarantee that one will obtain happiness, even when happiness is defined within its eighteenthcentury context. It is instead, an articulation of the idea that as humans we were created to live, at liberty, with the unalienable right to engage in the pursuit (CONKLIN, 2015, p. 262). ${ }^{3}$

Por sua vez, o preâmbulo da Constituição Francesa de 1958 faz referência ao texto preliminar da Declaração Francesa de 1789, que informa que as reclamações dos cidadãos, baseadas nos princípios incontestáveis, serviriam para a manutenção da Constituição Federal e a felicidade de todos (FRANÇA, 1958, 1798).

No Brasil, a já mencionada Proposta de Emenda à Constituição - PEC no 19/2010 fundamenta seu propósito na Carta Magna Japonesa - que alude ao tema quando, em seu artigo 13, determina que "todas as pessoas têm direito à busca da felicidade, desde que não interfira no bem-estar público" - assim como na Lei Maior Sul-coreana que, em seu artigo 10, demonstra que "todos têm direito a alcançar a felicidade, atrelando esse direito ao dever do Estado em confirmar e assegurar os direitos humanos dos indivíduos".

O mencionado projeto também traz o Reino do Butão como exemplo, que tem como indicador social o Índice Nacional de Felicidade Bruta - INFB, que capta os índices de "bem- estar, cultura, educação, ecologia, padrão de vida e qualidade de governo, determinando o artigo $9^{\circ}$ da Constituição o dever do INFB”. Contudo, Leal (2013), bebendo da fonte de Fernand de Varennes, aponta que a teoria da felicidade usada pela legislação butanesa é deturpada, afinal, as leis do local são autoritárias,

3 Como demonstrado nos Comentários de Blackstone e a Declaração da Independência, a busca da felicidade não é uma garantia legal de que será obtida felicidade, mesmo quando a felicidade é definida no século dezoito. É, em vez disso, uma articulação da ideia de que, como humanos, nós fomos criados para viver, em liberdade, com o inalienável direito de se engajar na busca. Tradução de responsabilidade destes autores. 
invisibilizadoras da diversidade populacional, bem como violadoras de direitos fundamentais e de minorias.

\section{O DIREITO À FELICIDADE COMO UM PRINCÍPIO}

Considerando a discussão acerca do alcance do direito à felicidade, como será visto adiante, é certo que o manto principiológico reveste sobremaneira tal instituto. Por conta disso, é inexitoso atribuirlhe caracteres de regra:

O direito à felicidade é um princípio, pois a ele não podemos conferir, prima facie, caracteres de regra. É até possível a emanação de uma regra que tenha como anteparo o direito à felicidade. Mas o direito em si, de fato, tem revestimento principiológico (LEAL, 2013, p. 205).

Leal (2013) prossegue afirmando que a felicidade está inserida no rol dos direitos fundamentais, pois que "simbolizam aspirações de igualdade, liberdade e segurança". O funcionamento desses direitos fundamentais é, de acordo com Canotilho apud Moraes (2015), composto por duas facetas: a de liberdade negativa - em que é defeso ao Estado interferir demasiadamente na esfera jurídica individual; e de liberdade positiva - em que os indivíduos podem exigir do Poder Público a concretização de tais direitos, bem como o preenchimento de omissões jurídicas.

Percebe-se que o prisma da materialização dos direitos fundamentais espelha os desdobramentos do direito amplo à felicidade, conforme será visto adiante. 


\subsection{Evolução da normatividade dos princípios}

Tratando-se da felicidade como programa social estatal a ser cumprido a partir da sua concretização como princípio do Direito, na sua presença implícita na vida das pessoas e seu ainda tímido aparecimento no ordenamento jurídico brasileiro, é necessário fazer uma abordagem sobre a importância atribuída aos princípios constitucionais nas duas correntes teóricas mais expressivas do Direito: positivismo e pós-positivismo.

De início, a corrente positivista ampliou a relevância os comandos legais expressos em detrimento dos postulados principiológicos. Isso ocorreu com o intuito de proteger a segurança jurídica, bem como a objetividade do sistema.

Consoante esse entendimento, bebendo da fonte de Gordillo Cañas, Bonavides (2011) asseverou que os princípios, no juspositivismo, entraram nos Códigos não como superiores à lei, mas como "válvulas de escape" para as normas jurídicas, por terem caráter subsidiário.

Dessa forma, no contexto positivista, o jurista, ao pesar entre a regra e o princípio, quando necessário o deslinde de caso concreto, optaria pela primeira, ante a sua superioridade normativa. $\mathrm{O}$ fato de estar positivada uma norma traria maior segurança jurídica, o que não seria possível com a abstração advinda dos princípios. Estes, na ordem constitucional, eram mantidos como juridicamente irrelevantes, pois não eram cobertos com o manto da normatividade.

Essa ótica mudou no decorrer dos tempos. Segundo Bonavides apud Pereira (2006), com o pós-positivismo, os postulados principiológicos foram investidos de normatividade e se equipararam às regras jurídicas. Assim, são agora tratados como direitos, especialmente nas Constituições advindas após as grandes guerras mundiais. 
Assim, compreende-se que, em tal conjuntura, os princípios não se diferenciam mais das regras, mas se tornam uma ramificação delas, sem lhes tirar o valor.

Em suma, os mesmos olhos que são voltados para as regras também notam os princípios; por conseguinte, eleva-se a sua importância dentro do arcabouço jurídico, dotando-os inclusive de normatividade.

É com o pós-positivismo que as ideias trazidas pelo jusnaturalismo e juspositivismo são quebradas. Seguindo essa afirmação, Bonavides (2011, p. 274-275) faz alusão ao trabalho de Dworkin:

$\mathrm{Na}$ análise crítica ao positivismo, Dworkin proclama que, se tratarmos princípios como direito, faz-se mister rejeitar três dogmas dessa doutrina.

O primeiro, diz ele, é o da distinção entre o Direito de uma comunidade e os demais padrões sociais (social standards) aferidos por algum test na forma de regra suprema (máster rule). O segundo - prossegue - referente à doutrina da discrição judicial - a "discricionariedade do juiz". E, finalmente, o terceiro, compendiado na teoria positivista da obrigação legal, segundo a qual uma regra estabelecida de Direito - uma lei - impõe tal obrigação, podendo ocorrer, todavia, a hipótese de que num caso complicado (hard case), em que tal lei não se possa achar, inexistiria a obrigação legal, até que o juiz formulasse nova regra para o futuro. E, se a aplicasse, isto configuraria legislação $e x$ post facto, nunca o cumprimento de obrigação já existente.

A partir da concepção de Dworkin, haveria a necessidade da tratativa dos princípios como direitos, pois tanto um conjunto complexo de postulados principiológicos, quanto uma regra positivamente imposta podem estabelecer obrigações legais. (BONAVIDES, 2011). 


\subsection{Da distinção entre princípios e regras}

Conforme apontamento de Miranda (2016), em tom uníssono com os ditames pós- positivistas, o Direito não é um conjunto de regras avulsas, mas uma estrutura tão complexa quanto as relações sociais de institutos significativos.

A sociedade, de per si, já abraça um eixo diversificado de relações entre indivíduos. Dentro dela há um pluralismo de grupos de pessoas que se associam entre si, celebrando aí a complexidade das relações sociais.

Desse modo, o campo social é complexo e, para que o Direito o contenha, não poderá estar imune a tal complexidade. Todavia, ao contrário da sociedade, a ciência jurídica deve ser organizada de forma que tenha significação para reger os demais agrupamentos sociais.

Bem por isso, dessa estruturação, além de outros institutos jurídicos, surgiram os princípios e as regras, que se tornaram equiparáveis no percorrer histórico.

Por consectário lógico, hodiernamente, não há falar-se em princípios fora do eixo do Direito, pois eles também estão dentro da célula em que se encontram todos os demais institutos jurídicos, cada um com sua função. Os princípios junto às regras formam as espécies da norma, que é lida como gênero. Neste teor:

Os princípios não se colocam, pois, além ou acima do Direito (ou do próprio Direito positivo); também eles numa visão ampla, superadora de conceitos positivistas, literalistas e absolutizantes das fontes legais - fazem parte do complexo ordenamental. Não se contrapõem às normas, contrapõem-se tão somente às regras; as normas jurídicas é que se dividem em normas-princípios e em normas-regras (MIRANDA, 2016, p. 260). 
Afirma-se, de acordo com Cianciardo (2003), em teor harmônico a Miranda (2016), que na polpa das normas fundamentais existem normas que são princípios e normas que são regras, que não se excluem entre si:

Dentro de las normas jusfundamentales es posible distinguir normas que son principios y normas que son reglas. Unas no excluyen a las otras. Las preguntas acerca de qué es un principio y qué es una regla sólo pueden ser respondidas cabalmente una vez que uno y otra han sido distinguidos. Los criterios que se han sugerido para ello son muy variados y hasta cierto punto complementarios (CIANCIARDO, 2003, p. 894). ${ }^{4}$

De fato, ambos os postulados convivem como irmãos dentro do ordenamento. E como toda irmandade, os protagonistas desse laço são diferentes, apesar de pertencerem à mesma família: às vezes entram em conflito, mas acabam convivendo de forma harmônica.

Independente da ciência abordada, princípio é "o fundamento, aquilo de que todas as outras coisas são derivadas, ele próprio não sendo derivado nem deduzido de nada”. (IGLÉSIAS, 2005, p. 25).

Em sua obra, Ávila (2015), após traçar a evolução histórica dos critérios de diferenciação entre as normas-princípios e as normas-regras, trouxe à baila os fatores de distinção empregados usualmente. Em primeiro lugar, o critério hipotético-condicional, em que a regra possui uma hipótese e uma consequência predeterminantes para a decisão, enquanto os princípios indicam apenas o fundamento.

Em segunda posição, Ávila (2015) trata do critério do modo final

4 Dentro das normas fundamentais do Direito é possível distinguir normas que são princípios e normas que são regras. Umas não excluem as outras. As perguntas acerca do que seja um princípio e do que seja uma regra só podem ser cabalmente respondidas uma vez que uma ou outra tenham sido distinguidas. Os critérios que são sugeridos para elas são muito variados e, em até certo ponto, complementares. Tradução de responsabilidade destes autores. 
de aplicação, em que as regras são aplicadas de forma absoluta, enquanto os princípios são observados de forma gradual - nas palavras do autor, de forma "mais ou menos".

Em terceiro lugar, o autor traz o critério do relacionamento normativo, em que o conflito de regras é solucionável mediante declaração de invalidade de uma ou com a criação de uma exceção, ao passo que o conflito principiológico é solucionável mediante ponderação, em que será avaliado o peso de cada axioma de forma singular.

E, por fim, Ávila (2015) aborda o quarto critério, que é o do fundamento axiológico, que estampa os princípios como fundamentos axiológicos para embasar a decisão tomada, ao contrário das regras.

\section{DESDOBRAMENTOS DO DIREITO AMPLO À FELICIDADE A PARTIR DA SUA APLICAÇÃO JURÍDICA}

Cuidando-se a felicidade de um axioma norteador, é imperioso destacar as perspectivas do princípio ora em estudo a partir de sua aplicação jurídica. Escorando-se no trabalho de Leal (2013), vislumbramse três vieses: 1) o liberal ou negativo - direito à busca da felicidade; 2) positivo - direito prestacional à felicidade; e 3) como telos do provimento jurisdicional.

\subsection{Viés liberal ou negativo - direito à busca da felicidade}

Esse desdobramento se revela em duas perspectivas, de um lado, o Estado não interfere ilegitimamente na deliberação de projetos pessoais e escolhas legítimas de cada indivíduo; de outro, o ser humano é livre para decidir sobre as questões de sua vida, de forma legítima. Saliente-se 
que legítima é a preferência ou o desejo que não deságue nos prazeres perversos - o que fere a dignidade da pessoa humana - nem macule a bolha jurídica de outros cidadãos (LEAL, 2013, p. 206).

No decorrer de suas lucubrações, Leal (2013) faz duas advertências relevantes. Na primeira observação, o jurista aduz que eventuais interferências do Estado no direito à busca da felicidade do indivíduo obrigam fundamentações, tendo em vista que essa atuação cercearia a liberdade do ser a buscar sua própria felicidade.

Na segunda observação, Leal (2013) assevera que, embora invoque a liberdade, o direito à busca da felicidade não se confunde com tal, pois possui "roupagem própria, com caracteres exclusivos, funcionando como fundamento de validade, inclusive de subsistemas jurídicos".

\subsection{Viés positivo - direito prestacional à felicidade}

Como mencionado anteriormente, Aristóteles já considerava os bens materiais e o mundo exterior na construção da felicidade, atribuindo a ela um viés positivo.

Segundo Leal (2013), esse pensamento deposita na bolha jurídica dos indivíduos o direito que eles têm de concretizar suas aspirações direito à busca da felicidade -, mediante o comportamento positivo do Estado de lhes fornecer instrumentos auxiliares na satisfação dessas preferências e interesses legítimos.

Invocada pelos utilitaristas clássicos como felicidade, essa ideia de atuação positiva estatal é terminologicamente alterada pelo utilitarismo moderno para bem estar social, nomenclatura que se encontra presente na Constituição Federal Brasileira de 1988. O significado da expressão 
"bem estar social" contida na Carta Magna é similar ao proposto por Bentham, que conceitua como sendo a aspiração de segurança pelas pessoas, abrangendo alimentação adequada e abrigo, além de mais segurança contra eventuais hostilidades (LEAL, 2013, p. 209).

No ponto, Tim Mulgam apud Leal (2013) corrobora a perspectiva de Bentham quando diz que "[...] os seres humanos têm determinadas necessidades básicas: do essencial para a vida, de segurança, de abrigo, de estabilidade social para fazer planos para o futuro e assim por diante. São os 'interesses de segurança"'.

Prosseguindo, adverte o autor (2013) que, embora as situações do bem estar social e do mínimo existencial tragam determinado nível de segurança às pessoas, não exaurem a carga de eficácia do direito prestacional à felicidade. Afinal, os recursos prestados pelo Estado não são limitados pelo rol dos direitos sociais. A concretização desses objetivos resulta na criação de outras novas metas.

Assim, Leal (2013) prossegue afirmando que o direito à felicidade é maior que o suprimento de necessidades básicas - está para além. $\mathrm{O}$ mínimo existencial confere segurança. Todavia, não assegura condições de planejamento e execução de preferências ou desejos legítimos. No máximo, irá garantir ao sujeito despossuído o início da busca pela sua felicidade. Conforme aponta Leal (2013, p. 213):

Enquanto a dignidade da pessoa humana acolhe o mínimo existencial como plataforma econômica de viabilidade da dignidade, o direito à felicidade faz uso dessa plataforma, mas marcha em direção ao desenvolvimento humano nas suas mais elevadas acepções cujos resultados são desfrutados por toda a sociedade . 


\subsection{Direito ao ambiente ecologicamente equilibrado e à paz}

Tratando-se o direito prestacional à felicidade como meta estatal obrigatória, faz-se pertinente associá-lo aos direitos ao ambiente

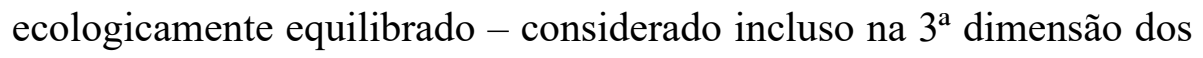

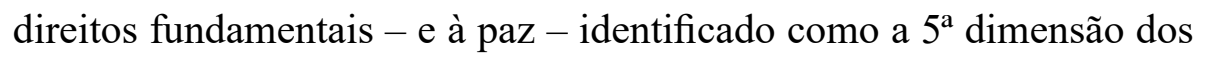
ditos direitos. O primeiro está calcado no Capítulo VI do Título VIII - da Ordem Social, da Constituição Federal vigente, e o segundo alçado como princípio constitucional - manto que lhe traz a mesma força normativa que os direitos fundamentais - no artigo $4^{\circ}$, VI e VII, do mesmo diploma legal.

À luz dos apontamentos de Dirley da Cunha Júnior. (2012), "meio ambiente" é o "conjunto das condições de existência humana, que integra e influencia o relacionamento entre os homens, sua saúde e seu desenvolvimento". Com isso, infere-se que quanto mais equilibrado for o ambiente cujo indivíduo esteja inserido, melhor a sua qualidade de vida e, portanto, o seu sentimento de satisfação perante suas expectativas e necessidades (BRASIL, 2013b, p. 29).

É consagrada, segundo Alexandre de Moraes (2015), pela atual Carta Magna Brasileira, a proteção efetiva ao ambiente ecologicamente equilibrado, considerado bem de uso comum do povo e essencial à sadia qualidade de vida individual e coletiva. Esse resguardo, como aduz Moraes (2015), suscita "a utilização de todos os meios legislativos, administrativos e judiciais necessários à sua efetiva proteção, que possui um regime jurídico especial exorbitante do Direito Comum". (MORAES, 2015, p. 881).

$\mathrm{O}$ enquadramento do meio ambiente como patrimônio comum da humanidade enseja a sua proteção integral, evitando prejuízo à 
coletividade, em face de uma afetação de certo recurso natural a uma finalidade individual (MORAES, 2015, p. 882).

Quanto à paz, Bonavides (2011) consagra-a como direito supremo da humanidade, considerando-a em sua "dimensão perpétua e caráter universal". O jurista propõe a visualização de tal direito "em sua feição agregativa de solidariedade, plano harmonizador de todas as etnias, de todas as culturas, de todos os sistemas, de todas as crenças que a fé e a dignidade do homem propugnam, reivindicam, concretizam e legitimam”. (BONAVIDES, 2011, p. 611). Prossegue advertindo que qualquer mácula e negação ao direito à paz acarretariam em crime contra a sociedade humana.

Ante tais considerações, deduz-se que o meio ambiente ecologicamente equilibrado e a paz figuram como condições básicas para a preservação da felicidade individual e coletiva, haja vista que, a contrário senso, a degradação ambiental - cite-se como exemplo o desastre da barragem de rejeitos de Mariana, em Minas Gerais ${ }^{5}$ - e a insegurança da violência - como exemplo, a tensão experimentada pela população do Rio de Janeiro/ $\mathrm{RJ}^{6}$ à vista dos confrontos entre criminosos e policiais - prejudicam a qualidade de vida humana.

\subsection{Como telos do provimento jurisdicional}

Partindo da colocação de que o papel prestacional do Estado na

5 "Um estudo da UFMG revelou este ano que $28,9 \%$ dos atingidos pela tragédia da Samarco sofrem de depressão, um percentual cerca de cinco vezes maior do que o da população brasileira, segundo dados da Organização Mundial de Saúde (OMS)". (AZEVEDO, 2018).

6 "A tensão, o medo e a incerteza diária têm um impacto direto nos estudos. "Esse acúmulo de influências negativas faz com que crianças em situação de guerra tenham uma memória recente mais curta, o que afeta a aprendizagem', afirma Yvonne Bezerra de Mello, idealizadora do Projeto Uerê, que auxilia crianças e adolescentes com dificuldades de aprendizagem relacionadas a traumas provocados pela violência na comunidade". (SEMIS, 2018). 
busca da felicidade pelos indivíduos e coletividades seja significativo, é possível que haja a debilitação de felicidades individuais quando houver necessidade de manutenção da felicidade coletiva, conforme aponta Leal (2013, p. 218):

É possível supor regras que vedem aos indivíduos interferirem nos projetos alheios de felicidade. Também é importante saber que a criação e manutenção da felicidade coletiva pode implicar no sacrifício de felicidades individuais, desde que não fragilizadores da dignidade da pessoa humana. A felicidade coletiva é a meta. Isso não se dá simplesmente ampliando o gozo do direito à busca da felicidade, no sentido de se lhe afastar vedações nem impor deveres para alcançá-lo.

A partir dessa perspectiva, Leal (2013) sustenta que, diante da colisão de direitos fundamentais e princípios constitucionais, a felicidade, como telos das decisões judiciais, pode ser utilizada como critério de ponderação. Esclarece que não seria um pilar essencial da jurisdição institucional, pois, mencionando o pensamento de Derek Bob, os julgadores não podem decidir de acordo com a vontade das massas só para satisfazer a felicidade coletiva, afinal, devem ser respeitados os moldes da Constituição Federal.

Tal perspectiva, para Alexy e Mill, espelha nada mais do que um utilitarismo revisitado (ALEXY; MILL apud LEAL, 2013, p. 289).

Apoiado no raciocínio de Richard Posner para o uso da felicidade como telos, Leal (2013) traz a sugestão de unir os parâmetros de ponderação atualmente utilizados pela jurisdição constitucional - em que se analisa qual princípio predomina em cada caso singularmente considerado - ou a recomendação dada pela doutrina especializada, com a possibilidade dos critérios de ponderação utilitaristas, balizando-se nos direitos fundamentais. 
Bentham (apud LEAL, 2013) adverte que a felicidade não pode ser utilizada constantemente como parâmetro pelos juízes, afinal o processo deve ser "perseguido previamente a cada julgamento moral, ou em cada operação legislativa ou judicial". (BENTHAM apud LEAL, 2013, p. 290).

É perigoso sombrear todas as lides na árvore da teoria da felicidade, o que, aliado à falta de informações consistentes, poderia acarretar diversos julgados envoltos de "achismos", com falsos prognósticos que não se confirmariam com o tempo. Isso colocaria o prestígio das Cortes em perigo. Leal (2013, p. 290-291) exemplifica:

[...] O Congresso Nacional aprovou uma lei criminalizando o uso, em rituais religiosos da ayahuasca, mais conhecida como "chá do Santo Daime". Uma ação questiona, no STF, se essa criminalização seria compatível com a liberdade de crença (art. $2^{\circ}, \S 1^{\circ}$, da Constituição).

Caminhando pela trilha da liberdade, essencial à teoria da felicidade, seria possível imaginar uma decisão que imaginasse que a liberação do consumo, como um meio menos gravoso em relação à liberdade, poderia afastar os perigos associados a essa substância e a seu comércio ilegal de forma tão ou mais eficiente que a criminalização. Outra posição, voltada para a segurança, defenderia que há registros de efeitos colaterais graves e que o efeito alucinógeno gerado pela chá é igual ou mais intenso ao gerado pelo consumo de outras ervas, que são, no Brasil, proibidas. Há uma quantidade imensa de variáveis que afastam da jurisdição constitucional a possibilidade de decidir a questão, pela teoria da felicidade, com segurança. Uma decisão nessa hipótese, poderia se dar por meros achismos. O Tribunal [...] poderia dizer, por exemplo, que o consumo não acarretaria qualquer problema. Anos depois, a medicina provaria o contrário. Então o Supremo teria entrado num tipo de aventura absolutamente desnecessária e isso se daria pelo fato de a Corte ter diante de si um caso sobre o qual a teoria da felicidade não 


\section{EXPERIÊNCIA JURISPRUDENCIAL BRASILEIRA}

Ainda que implícito, o direito à felicidade já coadjuvou julgados do Supremo Tribunal Federal - STF, conforme se vê a seguir:

No julgamento do Agravo de Instrumento - AI n ${ }^{\circ}$ 548.146/AM, em que se discutiu o cabimento do adicional de $20 \%$ do salário dado a um servidor público aposentado do Estado do Amazonas, o Relator Ministro Carlos Velloso, ao levar em consideração o princípio da busca à felicidade como implícito no ordenamento, escorou-se nele para fortalecer a aplicação do princípio da boa-fé e justificar sua decisão, ipsis litteris:

Parece evidente que a concessão da gratificação, com a aposentadoria, deu-se com observância do princípio da boa-fé. Ela tem, por outro lado, caráter alimentar. Ora, retirá-la, a esta altura, quando ela, efeito da lei estadual, está placitada pela ordem jurídico-constitucional vigente, não teria sentido. Retirá-la, quando a sua concessão viuse coberta pelo princípio da boa-fé, representaria ofensa a esse princípio, certo, convém registrar, que uma das razões mais relevantes para a existência do direito está na realização do que foi acentuado na Declaração da Independência dos Estados Unidos da América, de 1776, o direito do homem de buscar a felicidade. Noutras palavras, o direito não existe como forma de tornar amarga a vida dos seus destinatários, senão de fazê-la feliz (BRASIL, 2005).

Já no Recurso Extraordinário - RE no 370.212/RS, um posto de gasolina sofreu do Fisco penhora sobre parcela de seu faturamento. Em sua defesa, o estabelecimento alegou violação a dispositivos que tratam 
de livre iniciativa, concorrência e livre associação para fins lícitos. No deslinde do caso, o relator Min. Joaquim Barbosa menciona a obrigação estatal para com as aspirações que dizem ao sucesso, à felicidade e ao bem comum:

[...] a Constituição não contém nenhuma disposição que obrigue o cidadão a ter sucesso econômico ou profissional. Também não se espera que as pessoas lançadas à sorte em empreendimentos empresariais tenham sempre capacidade administrativa pujante. $\mathrm{O}$ direito fundamental assegurado na Carta Magna refere-se ao dever do Estado de permitir e prover os meios para a busca do sucesso, da felicidade e do bem comum (BRASIL, 2010b).

Quanto à realização de pesquisas científicas para fins terapêuticos com células-tronco embrionárias, no julgamento da Ação Direta de Inconstitucionalidade - ADI 3.510/DF, o Min. Celso de Mello, fazendo parte da maioria do quórum que declarou a constitucionalidade da temática, menciona o direito à felicidade ao declarar em seu voto:

O que já significa incorporar o advento do constitucionalismo fraternal às relações humanas, a traduzir verdadeira comunhão de vida ou vida social em clima de transbordante solidariedade em benefício da saúde e contra eventuais tramas do acaso e até dos golpes da própria natureza. Contexto de solidária, compassiva ou fraternal legalidade que, longe de traduzir desprezo ou desrespeito aos congelados embriões "in vitro", significa apreço e reverência a criaturas humanas que sofrem e se desesperam. Inexistência de ofensas ao direito à vida e da dignidade da pessoa humana, pois a pesquisa com célulastronco embrionárias (inviáveis biologicamente ou para os fins a que se destinam) significa a celebração solidária da vida e alento aos que se acham à margem do exercício concreto e inalienável dos direitos à felicidade e do viver com dignidade (BRASIL, 2008). 
Acresça-se, por pertinente, que a Resolução-CNJ n ${ }^{\circ} 175$, de 14 de maio de 2013, emitida pelo Conselho Nacional de Justiça, é considerada um marco na história do Direito brasileiro, haja vista dispor sobre a habilitação de casamento e conversão em união estável, entre pessoas do mesmo sexo (BRASIL, 2013a). Além de outras disposições, o referido diploma normativo é calcado em julgamentos do STF, quais sejam a Arguição de Descumprimento de Preceito Fundamental - ADPF $\mathrm{n}^{\circ}$ 132/RJ e a ADI n ${ }^{\circ} 4277 / \mathrm{DF}$. Tanto esta quanto aquela trazem, em seu âmago, a felicidade como fundamento para o exercício do direito de casar ou conviver, inclusive associando-a à dignidade da pessoa humana (BRASIL, 2011b, 2011a).

No julgamento da ADPF n ${ }^{\circ} 132 / R J$, cuja discussão versou sobre o reconhecimento do status de entidade familiar aos casais homoafetivos em regime de união estável, houve, além da associação do direito à busca da felicidade como corolário da dignidade da pessoa humana, a menção à vedação do Estado em obstar que os indivíduos busquem seus projetos pessoais de felicidade, desde que legítimos. Para o Min. Celso de Mello (apud COSTA, 2015, p. 18) "quando o Congresso se omitiu na disciplina normativa a respeito da união estável entre casais homoafetivos, houve um ataque ao princípio da busca pela felicidade, pois restaram maculados os direitos fundamentais deste grupo de indivíduos". Também foi no voto do Ministro que ele prolatou os seguintes dizeres:

[...] entendo que a extensão, às uniões homoafetivas, do mesmo regime jurídico aplicável à união estável entre pessoas de gênero distinto justifica-se e legitimase pela direta incidência, dentre outros, dos princípios constitucionais da igualdade, da liberdade, da dignidade, da segurança jurídica e do postulado constitucional implícito que consagra o direito à busca da felicidade, os 
quais configuram, numa estrita dimensão que privilegia o sentido de inclusão decorrente da própria Constituição da República (art. $1^{\circ}$, III, e art. $3^{\circ}$, IV), fundamentos autônomos e suficientes aptos a conferir suporte legitimador à qualificação das conjugalidades entre pessoas do mesmo sexo como espécie do gênero entidade familiar (BRASIL, 2011c).

O posicionamento acima destacado é reiterado pelo mesmo Ministro, quando, no julgamento do $\mathrm{RE} \mathrm{n}^{\mathrm{o}}$ 477.554/MG, destacou o direito à busca da felicidade, afirmando, dentre diversos momentos, ser o tal um "verdadeiro postulado constitucional implícito, como expressão de uma ideia-força que deriva do princípio da essencial dignidade da pessoa humana". É, inclusive, inserindo no rol de princípios fundamentais que, assim como na ADPF $n^{\circ} 132 / \mathrm{RJ}$, ele motiva sua decisão, in verbis:

Vale referir [...] que o magistério da doutrina - apoiandose em valiosa hermenêutica construtiva e invocando princípios fundamentais (como os da dignidade da pessoa humana, da liberdade, da autodeterminação, da igualdade, do pluralismo, da intimidade, da não discriminação e da busca da felicidade) - tem revelado admirável percepção quanto ao significado de que se revestem tanto o reconhecimento do direito personalíssimo à orientação sexual quanto a proclamação da legitimidade ético-jurídica da união homoafetiva como entidade familiar, em ordem a permitir que se extraiam, em favor de parceiros homossexuais, relevantes conseqüências no plano do Direito, notadamente no campo previdenciário, e, também, na esfera das relações sociais e familiares (BRASIL, 2011c).

\section{CONCLUSÃO}

A felicidade é algo que integra os anseios humanos. É difícil 
precisar o seu significado, embora haja inúmeras correntes teóricas que tentam conceituá-la. Malgrado seja árduo atribuir uma definição meticulosa, é inegável seu ainda tímido aparecimento dentro do Direito.

Seja individual, seja coletivo, o direito à felicidade vem se expressando no mundo jurídico em forma de princípio constitucional implícito. O ganho de normatividade que os princípios alcançaram com a transição do positivismo para o pós-positivismo permitiu sua elevação no ordenamento jurídico brasileiro. Esse revestimento principiológico permite visualizar o direito amplo à felicidade em diversas perspectivas a partir de sua aplicação, desdobrando-se em um viés negativo ou liberal - direito à busca da felicidade; positivo - direito prestacional à felicidade; e como telos das decisões judiciais quando acometidas de colisão de princípios.

O impacto mais importante da análise do revestimento principiológico do direito à felicidade é, indubitavelmente, a sua manipulação jurídica, não somente compondo pedidos feitos ao Judiciário, mas, sobretudo, integralizando decisões judiciais, como elemento de ponderação em casos de difícil resolução, em que há conflito aparente de normas ou de princípios.

A despeito de sua aparição, que ainda engatinha no Direito brasileiro, o direito à felicidade é positivado em algumas constituições internacionais, como nos Estados Unidos, França, Japão, Coréia do Sul e no Reino de Butão. Essa realidade demonstra uma preocupação em torno da felicidade humana.

No Brasil, o seu aparecimento expõe uma necessidade de se discutir ainda mais essa temática voltada para a seara jurídica.

As discussões acerca do direito ora estudado, seu impacto e desdobramentos na vida humana devem ser fomentadas seja dentro, 
seja fora dos bancos acadêmicos. A precariedade doutrinária acerca do direito à felicidade constitui um obstáculo, mas não um impedimento. É necessário debruçar-se sobre leituras e indagações, tanto filosóficas quanto das demais áreas contributivas do Direito. Isso auxiliará o tema no ganho de robustez e profundidade jurídica, tal como vem ganhando expressividade nas diversas pretensões e decisões judiciais, especialmente naquelas em que há conflito aparente de normas ou de princípios.

Discorrer sobre o direito à felicidade e seus desdobramentos pode ser, à primeira vista, complexo. Entretanto, o progresso pessoal e intelectual que se faz ao pensar sobre a existência jurídica da felicidade é de grande valia, pois ser feliz constitui um desejo básico que todo indivíduo leva em consideração ao exercer seus atos e realizar seus desejos legítimos. Ou seja, ser feliz é um sentimento que transcende a mera existência material.

\section{REFERÊNCIAS}

ARISTÓTELES. Ética a Nicômaco. Tradução: Pietro Nassetti. São Paulo: Martin Claret, 2003.

ÁVILA, Humberto. Teoria dos princípios: da definição à aplicação dos princípios jurídicos. 16. ed. São Paulo: Malheiros, 2015.

AZEVEDO, Ana Lúcia. Em Mariana, depressão assombra vítimas de tragédia. O Globo, Rio de Janeiro, 24 jun. 2018. Disponível em: $<$ https://oglobo.globo.com/brasil/em-mariana-depressao-assombravitimas-de-tragedia-22815793>. Acesso em: 11 jul. 2018.

BITTAR, Eduardo Carlos Bianca. Curso de ética jurídica: ética geral e profissional. 8. ed. São Paulo: Saraiva, 2011. 
BONAVIDES, Paulo. Curso de Direito Constitucional. 27. ed. São Paulo: Malheiros, 2011.

BRASIL. Conselho Nacional de Justiça. Resolução no ${ }^{0}$ 175, de 14 de maio de 2013. Brasília, DF, 2013a. Disponível em: $<$ http://www. cnj.jus.br/images/imprensa/resolu\%C3\%A7\%C3\%A3o_n_175.pdf $>$. Acesso em: 13 nov. 2016.

BRASIL. Ministério da Saúde. Secretaria-Executiva. Secretaria de Vigilância em Saúde. Glossário temático: promoção da saúde. Brasília, DF: Ministério da Saúde, 2013 b.

BRASIL. Senado Federal. Proposta de emenda à constituição $\mathbf{n}^{0}$ 19, de 7 de julho de 2010. Altera o artigo $6^{\circ}$ da Constituição Federal para incluir o direito à busca da Felicidade por cada individuo e pela sociedade, mediante a dotação pelo Estado e pela própria sociedade das adequadas condições de exercício desse direito. Brasília, DF, 2010a. Disponível em: <http://www.senado.gov.br/atividade/materia/ getTexto.asp?t=80759>. Acesso em 17 out. 2016.

BRASIL. Supremo Tribunal Federal. Ação direta de inconstitucionalidade $n^{0}$ 3.510/DF. Relator: Min. Ayres Britto. Brasília, DF, 29 maio 2008. Disponível em: <http://redir.stf.jus.br/ paginadorpub/paginador.jsp?docTP $=\mathrm{AC} \& \operatorname{doc} \mathrm{ID}=611723>$. Acesso em: 13 nov. 2016.

BRASIL. Supremo Tribunal Federal. Ação direta de inconstitucionalidade $n^{0}$ 4.277/DF. Relator: Min. Ayres Britto. Brasília, DF, 5 maio 2011a. Disponível em: <http://www.stf.jus.br/ portal/inteiroTeor/obterInteiroTeor.asp?id $=628635>$. Acesso em: 13 nov. 2016.

BRASIL. Supremo Tribunal Federal. Agravo de Instrumento $\mathbf{n}^{\mathbf{0}}$ 548.146/AM. Relator: Min. Carlos Velloso. Brasília, DF, $22 \mathrm{dez}$. 2005. Disponível em: $<$ http://www.stf.jus.br/portal/jurisprudencia/ 
visualizarEmenta.asp?s1 $=000010496 \&$ base $=$ base Monocraticas $>$. Acesso em: 13 nov. 2016.

BRASIL. Supremo Tribunal Federal. Arguição de descumprimento de preceito fundamental $\mathbf{n}^{\mathbf{0}}$ 132/RJ. Relator: Min. Ayres Britto. Brasília, DF, 5 maio 2011b. Disponível em: <http://redir.stf.jus.br/ paginadorpub/paginador.jsp?docTP $=\mathrm{AC} \&$ doc $\mathrm{ID}=628633>$. Acesso em: 13 nov. 2016.

BRASIL. Supremo Tribunal Federal. Recurso Extraordinário no 370.212/RS. Relator: Min. Joaquim Barbosa. Brasília, DF, 8 set. 2010b. Disponível em:<http://www.stf.jus.br/portal/jurisprudencia/ visualizarEmenta.asp?s1=000103967\&base=base Monocraticas $>$. Acesso em: 13 nov. 2016.

BRASIL. Supremo Tribunal Federal. Recurso Extraordinário no 477.554/MG. Relator: Min. Celso de Mello. Brasília, DF, 2 ago. 2011c. Disponível em: <http://stf.jus.br/portal/processo/ verProcessoTexto.asp? $\mathrm{id}=3020473 \&$ tipoApp $=\mathrm{RTF}>$. Acesso em: 13 nov. 2016.

CIANCIARDO, Juan. Principios y reglas: una aproximación desde los criterios desde los criterios de distinción. Boletín Mexicano de Derecho Comparado, Ciudad de México, v. 36, n. 108, p.891-906, sept./dic. 2003.

CONKLIN, Carli. The origins of the pursuit of happiness.

Washington University Jurisprudence Review, Washington, v. 7, n. 2, p. 195-262, 2015. Disponível em: <https://openscholarship.wustl. edu/cgi/viewcontent.cgi? article $=1123 \&$ context $=$ law_jurisprudence $>$. Acesso em: 17 out. 2016.

COSTA, Arthur de Oliveira Calaça. Direito à busca da felicidade: análise do princípio enunciado no julgamento da ADPF 132 à luz da teoria de Ronald Dworkin. Caderno Virtual, Brasília, v. 2, n. 31, 
2015.

CUNHA JÚNIOR, Dirley da. Curso de direito constitucional. 6. ed. Salvador: Juspodivm, 2012.

EPICURO. Carta sobre a felicidade (a Meneceu). Tradução e apresentação: Álvaro Lorencini; Enzo Del Carratore. São Paulo: Ed. UNESP, 2002.

FRANÇA. Constituição (1789). Déclaration des Droits de l'Homme et du Citoyen. Paris, 1789.

FRANÇA. Constituição (1958). Constitution du 4 octobre 1958. Paris, 1958.

GILBERT, Daniel. Stumbling on happiness. New York: Alfred A. Knopf, 2006.

IGLÉSIAS, Maura. Pré-Socráticos: físicos e sofistas. In: REZENDE, Antônio (Org.). Curso de Filosofia: para professores e alunos de segundo grau e de graduação. 13. ed. Rio de Janeiro: Zahar, 2005. p. $21-40$.

LAMY, Marcelo. Conceitos indeterminados: limites jurídicos de densificação e controle. Revista Internacional d'Humanitats, São Paulo, v. 10, n. 11, p. 53-58, 2007.

LEAL, Saul Tourinho. Direito à felicidade: história, teoria, positivação e jurisdição. 2013. 357 f. Tese (Doutorado em Direito Constitucional) - Pontifícia Universidade Católica de São Paulo, São Paulo, 2013. Disponível em: <https://sapientia.pucsp.br/bitstream/ handle/6202/1/Saul\%20Tourinho\%20Leal.pdf $>$. Acesso em: 20 set. 2016.

MILL, John Stuart. Utilitarismo. Tradução: Pedro Galvão. Porto: Porto Editora, 2005. 
MIRANDA, Jorge. Os grandes princípios constitucionais e a jurisprudência da crise em Portugal. In: LEITE, George Salomão et al. (Coord.). Ontem, os códigos! Hoje, as constituições: homenagem a Paulo Bonavides. São Paulo: Malheiros, 2016. p. 259-274.

MORAES, Alexandre de. Direito constitucional. 31. ed. São Paulo: Atlas, 2015.

PEREIRA, Rodolfo Viana. Hermenêutica filosófica e constitucional. 2. ed. Belo Horizonte: Del Rey, 2006.

RUBIN, Beatriz. O direito à busca da felicidade. Revista Brasileira de Direito Constitucional, São Paulo, n. 16, p. 35-49, jul./dez. 2010.

SEMIS, Laís. O que o luto da rede municipal do Rio diz sobre a violência que atinge as escolas. 2018. Disponível em: $<$ https://novaescola.org.br/conteudo/11902/o-que-o-luto-da-rede-municipal-do-rio-diz-sobre-a-violencia-que-atinge-as-escolas $>$. Acesso em: 11 jul. 2018 .

SOSNOWSKI, Alice. A felicidade, segundo o filósofo Mario Sergio Cortella. 2013. Disponível em: <https://exame.abril.com.br/carreira/ felicidade-carreira-e-maratona/> . Acesso em: 16 out. 2016.

TIBURI, Márcia Angelita. A felicidade é coletiva. Revista Vida Simples, São Paulo, p. 50-51, 1 maio 2007.

VAN BOVEN, Leaf. Experientialism, materialism, and the pursuit of happiness. Review of General Psychology, Washington, v. 9, n. 2, p. 132-142, 2005.

Como citar: SOUZA, Erik Almeida Rodrigues de; RAMOS, Zélia Maria Xavier; CORDEIRO, Chirley Vanuyre Vianna. Direito à felicidade: análise principiológica e desdobramentos no ordenamento jurídico brasileiro. Revista do Direito Público, Londrina, v. 13, n. 2, p.100137, ago. 2018. DOI: 10.5433/24157-108104-1.2018v13n2p100. ISSN: 


\section{0-511X.}

Recebido em: 18/07/2017

Aprovado em: 13/07/2018 